\title{
CAMBRIDGE UNIVERSITY NATURAL RADIOCARBON MEASUREMENTS II
}

\author{
H. GODWIN and E. H. WILLIS
}

Cambridge University*

The dates given have been obtained during the year 1959. They have been made with carbon dioxide at 2 atmospheres pressure in a proportional gas-counter, as for the series given in Radiocarbon Supplement, volume 1.

The bulk of the assays are made in conjunction with the various investigations of the staff and students of the University Sub-department of Quaternary Research. We wish to acknowledge the invaluable help of Mr. R. Burleigh, Technical Assistant in the Carbon Dating Lahoratory.

\section{SAMPLE DESCRIPTIONS \\ BRITISH ISLES \\ A. Somerset Levels series, Southwestern England (continued)}

We here give a number of dates extending the series described under this heading in the first Cambridge date list (Godwin and Willis, 1959).

Q-430. Shapwick Heath, Neolithic axe site $\quad 4540 \pm 130$

Wood ( $51^{\circ} 9^{\prime} 13^{\prime \prime} \mathrm{N}$ Lat, $2^{\circ} 38^{\prime} 47^{\prime \prime}$ W Long). At this site a polished stone axe of Graig Llwyd rock was found in 1957, from the base of the humified Sphagnum-Calluna peat just above the birch fen wood layer. The dated sample was wood from the top of the fen wood layer as it appeared within 2 or 3 yd laterally of the find. Coll. 1959 by H. Godwin. Comment: this gives a good approximation to the date of the axe, and helps to fix an important stratigraphic boundary, which is also measured by Q-115 and Q-116.

Q-115. Shapwick Heath, rooted birch, 1

$4010 \pm 120$

Wood of birch $\left(51^{\circ} 9^{\prime} 19^{\prime \prime} \mathrm{N}\right.$ Lat, $2^{\circ} 49^{\prime} 4^{\prime \prime}$ W Long), from a tree rooted in situ at junction of fen wood peat and overlying Sphagnum-Calluna peat. Coll. 1955 by H. Godwin.

Q-116. Shapwick Heath, rooted birch, la

$3580 \pm 120$

Peat $\left(51^{\circ} 9^{\prime} 9^{\prime \prime} \mathrm{W}\right.$ Lat, $2^{\circ} 49^{\prime} 4^{\prime \prime} \mathrm{W}$ Long $)$, from same site as Q-115 and immediately below it. Coll. 1955 by H. Godwin. Comment: rather surprisingly $400 \mathrm{yr}$ younger than Q-115, but possibly a chance effect.

Q-36. Shapwich Heath, rooted birch, $2 \quad 2250 \pm 110$

Wood $\left(51^{\circ} 9^{\prime} 9^{\prime \prime} \mathrm{N}\right.$ Lat, $2^{\circ} 48^{\prime} 18^{\prime \prime} \mathrm{W}$ Long), from near an exposure of the Shapwick Heath track. Birch tree in situ in fresh Sphagnum peat directly overlying the Cladium peat of the first (Iron Age) flooding of this area. Coll. 1953 by H. Godwin.

Q-357. Shapwick Railway Station, boat

$2305 \pm 120$

Wood ( $51^{\circ} 9^{\prime} 56^{\prime \prime} \mathrm{N}$ Lat, $2^{\circ} 49^{\prime} 30^{\prime \prime} \mathrm{W}$ Long), from monoxylous boat * Radiocarbon Dating Laboratory, 5 Salisbury Villas, Station Road, Cambridge, and University Sub-department of Quarternary Research, Botany School, Cambridge. 
dug up in 1906 and preserved in Taunton Castle Museum. After treatment to remove paraffin wax the sample was combusted. The hoat could only relate to one of the flooding episodes in the bog's history, and the carbon date shows it to have been the first and major Iron Age flooding.

\section{Q-427. Honeycat Track, Westhay Level, birch wood 1}

$4326 \pm 130$

Horizontal birch stems of trackway $\left(51^{\circ} 10^{\prime} 53^{\prime \prime} \mathrm{N} \mathrm{Lat,} 2^{\circ} 50^{\prime} 7^{\prime \prime} \mathrm{W}\right.$ Long). Coll. September 1959 by H. Godwin.

Q-320. Honeycat track, Westhay Level, wood $2 \quad 4065 \pm 130$ Wood from trackway $\left(51^{\circ} 10^{\prime} 53^{\prime \prime} \mathrm{N}\right.$ Lat, $2^{\circ} 50^{\prime} 7^{\prime \prime} \mathrm{W}$ Long). Coll. January 1959 hy H. Codwin.

\section{Q-429. Honeycat track, Westhay Level, alder stump}

$4215 \pm 130$

Wood ( $51^{\circ} 10^{\prime} 53^{\prime \prime}$ N Lat, $2^{\circ} 50^{\prime} 7^{\prime \prime}$ W Long), from stump of Alnus at track level and forming top layer of hirch wood peat on which trackway was built. Coll. September 1959 by H. Codwin.

Q-431. Honeygore track, Westhay Level $4750 \pm 130$

Wood from trackway $\left(51^{\circ} 10^{\prime} 53^{\prime \prime} \mathrm{N}\right.$ Lat, $2^{\circ} 50^{\prime} 10^{\prime \prime} \mathrm{W}$ Long). Coll. September 1959 by H. Godwin.

Q-460. Blakeway Farm track, Westhay Moor $4280 \pm 130$

Wood of horizontal stems of Corylus avellana (hazel) from the track at site where it was first excavated about $500 \mathrm{~m} \mathrm{SE}$ of Blakeway Farm $\left(51^{\circ}\right.$ $11^{\prime} 38^{\prime \prime} \mathrm{N}$ Lat, $2^{\circ} 47^{\prime} 54^{\prime \prime} \mathrm{W}$ Long). Wood kept in alcohol from 1944 when it had been collected by H. Godwin; it was baked to get rid of the alcohol before being combusted. This is the track described in Clapham and Godwin (1948), and it is evidently Neolithic. The hazel stems seem to have been derived from coppice growth. Along the same line, and $.5 \mathrm{mi} \mathrm{S}$, a track of similar dimensions was encountered in 1947/1948 near Toll Gate House. Samples Q-306 and Q-309 (Godwin and Willis, 1959) came from this site. They are wrongly named in our first date list and they should both be renamed "Toll Gate House Track"; this track is of the Late Bronze Age.

Q-311 bis. Viper's Platform, Shapwick Heath $\begin{array}{r}\mathbf{2 4 1 0} \pm 100 \\ \mathbf{2 4 6 0} \pm 110\end{array}$

(ca. $51^{\circ} 9^{\prime} 48^{\prime \prime} \mathrm{N}$ Lat, $2^{\circ} 49^{\prime} 5^{\prime \prime} \mathrm{W}$ Long). A repetition of the dating of the sample given as $24.10 \pm 100$ B.P. in our first date list has yielded a figure closely similar.

Q-313. Nidons track (Dewar's B), 1953-1955 2585 \pm 100

Mortised timber from trackway, Shapwick Heath, excavated by H. S. L. Dewar in 1953 and 1955 (51 $1^{\circ} 20^{\prime \prime}$ N Lat, $2^{\circ} 49^{\prime} 4^{\prime \prime}$ W Long).

Q-316. Nidons track (Dewar's B), peat

$2590 \pm 120$

Cladium mariscus peat, embedding timber of trackway, Shapwick Heath $\left(51^{\circ} 9^{\prime} 20^{\prime \prime} \mathrm{N}\right.$ Lat, $2^{\circ} 49^{\prime} 4^{\prime \prime} \mathrm{W}$ Long). Coll. 1959 by H. Godwin with Q-317 through Q-319. 
Q-317. Nidons track (Dewar's B), overlying peat $2628 \pm 120$

Peat $\left(51^{\circ} 9^{\prime} 20^{\prime \prime} \mathrm{N}\right.$ Lat, $2^{\circ} 49^{\prime} 4^{\prime \prime} \mathrm{W}$ Long), Shapwick Heath, immediately over the brushwood of the trackway. Coll. 1959 by H. Godwin.

\section{Q-318. Nidons track (Dewar's B), underlying peat}

$2642 \pm 120$

Peat $\left(51^{\circ} 9^{\prime} 20^{\prime \prime} \mathrm{N}\right.$ Lat, $2^{\circ} 49^{\prime} 4^{\prime \prime}$ W Long), Shapwick Heath, immediately below brushwood of trackway (at 50 to $55 \mathrm{~cm}$ depth). Coll. 1959 by H. Godwin.

Q-319. Nidons track (Dewar's B), deeper peat $2482 \pm 120$

Peat $\left(51^{\circ} 9^{\prime} 20^{\prime \prime} \mathrm{N}\right.$ Lat, $2^{\circ} 49^{\prime} 4^{\prime \prime}$ W Long), Shapwick Heath, below sample Q-318 (at 60 to $65 \mathrm{~cm}$ depth), probably reworked old SphagnumCalluna peat. Coll. 1959 by H. Godwin.

\section{Q-43. Shapwick Heath trackway (Foster's), Myrica}

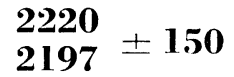

Wood of Myrica gale from just at or above level of trackway $\left(51^{\circ} 9^{\prime} 9^{\prime \prime}\right.$ $\mathrm{N}$ Lat, $2^{\circ} 48^{\prime} 18^{\prime \prime} \mathrm{W}$ Long), dated as Q-39. Comment: in good agreement with date for trackway wood itself $(Q-39,2470 \pm 110$, Godwin and Willis, 1959).

\section{General Comment on Somerset Levels Series}

In our first radiocarbon date list (Godwin and Willis, 1959) we reported that five trackways and an analogous wooden platform had been dated between 2470 and 2850 B.P., and that this confirmed pollen-analytic and archaeologic evidence that they were built in the Late Bronze Age in response to general water-logging of the bog surfaces. The dating of Nidons track now shows it to be sixth in the same series.

Although, in the case of those tracks already reported, there was a time gap between the trackway dates and those of the peat on which the tracks rest, at Nidons track it is evident that no such discontinuity occurs.

The radiocarbon dates confirm that in addition to the Late Bronze Age tracks there are present three tracks of Neolithic age dated between 4065 and 4750 B.P.; two of these are newly described. All three lie in pollen zone VIIb and close to the stratigraphic horizon, which indicates conversion of a fen woodland to an ombrogenous Sphagnum bog, possibly a swamping analogous to that which induced the Late Bronze Age trackways. The stratigraphic level of the polished stone axe from Shapwick Heath confirms the Neolithic age of the trackways and it has yielded a similar carbon date of 4540 B.P. The dating of the Blakeway Farm track establishes that a type of Corylus (hazel) coppice growt'. already existed in early Neolithic time, and that the beech (Fagus sylvatica) was then native.

The monoxylous boat from Shapwick Station could be inferred to have been deposited only during a flooding episode, and the carbon date of 2305 B.P. corresponds with the major flooding episode in the beginning of the Iron Age. 


\section{B. Full-glacial and Late-glacial Periods}

Q-25. Lea Valley Arctic Plant Bed, North London $28,000 \pm 1500$

Plant debris sieved off from the plant bed. Precise locality in the valley unknown, but probably Nazeing or Broxbourne $\left(51^{\circ} 45^{\prime} \mathrm{N}\right.$ Lat, $\mathrm{O}^{\circ}$ Long). Deposit described by S. H. Warren and others (see references in Godwin, 1956) was characterized by abundant arctic willows and a rich sub-arctic flora together with fauna including mammoth, reindeer, lemming, etc. The bed consists of large rafts of fine silt incorporated frozen into the coarse gravels of the lowest terrace of the River Lea. Above these gravels lie lateglacial deposits. Coll. 1950 or earlier by S. H. Warren. Comment: date gives a clear indication of the age of an example of the British full-glacial flora and fauna.

\section{Q-385. Colney Heath, Hertfordshire $\quad 13,560 \pm 210$}

Conifer and willow wood from large erratics of peat embedded in the upper layers of coarse gravels in the valley of the River Colne, a tributary of the Thames $\left(51^{\circ} 44^{\prime} 45^{\prime \prime} \mathrm{N}\right.$ Lat, $0^{\circ} 15^{\prime} 30^{\prime \prime} \mathrm{W}$ Long). Pollen analyses and plant macro-remains show a periglacial flora, and the beetle fauna (R. G. Pearson, unpub.) indicates sub-arctic conditions. Coll. 1959 by H. Godwin and R. G. Pearson. Comment: on stratigraphic grounds this peat must be between the Arctic Plant Bed (Q-25) and the Late-glacial in age; the fauna and flora are consistent with this; the carbon dates confirm it.

Wood $\left(50^{\circ} 29^{\prime} \mathrm{N}\right.$ Lat, $3^{\circ} 37^{\prime} \mathrm{W}$ Long $)$ from the upper layers of a brown detritus mud sealed in with gray gravelly clay, probably a solifluxion deposit. This is from a later exposure of the interstadial organic deposits described in our first carbon date list (Q-71, Godwin and Willis, 1959). Pollen analyses refer Q-304 to the beginning of Walker's pollen zone $\alpha$, which probably corresponds with the West European zone III, the zone of the younger Dryas (lays. The beetle fauna is shown by R. G. Pearson (unpub.) to have a pronouncedly boreal character. Coll. 1958 by R. G. Pearson. Comment: it is now thought possible that the date for the organic muds of Q-71 (12,810 \pm 180 , Godwin and Willis, 1959) may have been too old on account of inclusion of finely divided coal from the local boulder clays. The Q-304 wood sample escapes this charge, and its date goes a long way towards establishing the Allerød age of these St. Bees deposits, even though the date corresponds more closely to that usually given to the end of zone III rather than its commencement.

\section{Recurrence Surfaces}

\section{Tregaron SE bog series, Cardiganshire}

In the upper layers of all of the three raised bogs of the Gors Goch Glan Teifi there is a similar layer, about $8 \mathrm{~cm}$ thick, of very highly humified peat in the otherwise little-humified Sphagnum peat. This was interpreted as a "retardation layer," representing a phase of climatic dryness (Godwin and Mitchell, 1938). The following dates are from various layers in the SE raised 
bog $\left(52^{\circ} 15^{\prime} \mathrm{N}\right.$ Lat, $3^{\circ} 55^{\prime} \mathrm{W}$ Long). Sample Q-75 was from an older collection, made in 1937; the others were coll. 1959 by H. Godwin and J. Turner.

Q-75. Tregaron, retardation layer

$\mathbf{7 6 0} \pm \mathbf{7 0}$

Very humified peat from the center of the humified layer. Comment: cf. Q-390, Q-391.

Q-390. Tregaron, 18 to 19 in.

$768 \pm 90$

Sphagnum imbricatum peat lying immediately above the humified peat of the retardation layer, 18 to $19 \mathrm{in}$. depth. Comment: in good agreement with Q-75. Unpublished pollen analyses by J. Turner show considerable disforestation at this time which corresponds closely with foundation of the monastery of Strata Florida in the vicinity.

Q-391. Tregaron, 25 to 26 in.

$1477 \pm 90$

Sphagnum imbricatum peat lying immediately below the humified peat of the retardation layer at the site of collection of Q.390, 25 to 26 in. depth. Comment: surprisingly older than Q-390.

\section{Q-388. Tregaron, 66 to $66.75 \mathrm{in}$.}

$2669 \pm 110$

$2624 \pm 111$

Moderately humified Sphagnum peat $\left(52^{\circ} 15^{\prime} \mathrm{N}\right.$ Lat, $3^{\circ} 55^{\prime} \mathrm{W}$ Long), at 66 to $66.75 \mathrm{in}$. depth, immediately above the main recurrence surface of the bog. Attention was directed to this surface, where there is a very big and sudden change in degree of humification, by Godwin and Mitchell (1938); they showed that the surface was consistently developed, corresponded with a pollenzone boundary, and might be considered to represent the Sub-Boreal/SubAtlantic contact. Unpublished pollen analyses likewise suggest that it corresponds with the opening of English pollen zone VIII. Coll. 1959 by H. Godwin and J. Turner. Comment: the carbon date supports the pollen-analytic evidence.

\section{Q-389. Tregaron, 67.5 to $68.25 \mathrm{in}$.}

$$
3029 \pm 110
$$

$2879 \pm 110$

Highly humified Sphagnum peat at 67.5 to 68.25 in. depth, immediately under Q-388, and just below the main recurrence surface of the bog. Comment: sufficiently older than Q-388 to show the probability that bog growth had greatly slowed or ceased just before regeneration began above the recurrence surface.

\section{Lake District Mosses series}

The laboratory has in hand a number of samples investigated pollenanalytically and stratigraphically from this region. Q-83 is the first to be determined.

Q-83. Helsington Moss, Westmorland

$1514 \pm 100$

Peat $\left(54^{\circ} 17^{\prime} 30^{\prime \prime} \mathrm{N}\right.$ Lat, $2^{\circ} 49^{\prime} \mathrm{W}$ Long) from the upper retardation layer shown by Smith (1959) to extend across the upper layers of the bog. Coll. 1953 by A. G. Smith who, on pollen-analytic grounds, suggested that it might correspond with Granlund's RY II (ca. A.D. 400). Comment: Dr. Smith's prediction is confirmed. 


\section{Fenn's Moss series, Flintshire}

Sphagnum peat from various levels in peat works, Fenn's Moss $\left(52^{\circ} 56^{\prime}\right.$ N Lat, $2^{\circ} 45^{\prime}$ W Long). Samples from site A coll. March 1959 by H. Godwin and J. Turner; from site B, coll. September 1959 by J. Turner.

Q-392. Fenn's Moss, site A, 38 to $40 \mathrm{~cm} \quad 655 \pm 90$

Sphagnum peat from just above the uppermost recurrence surface, site A; probably corresponding with the uppermost described by Hardy (1939) from the same moss, and in her pollen zone VIII. Comment: cf. Q-393.

Q-393. Fenn's Moss, site A, 42 to $44 \mathrm{~cm} \quad 746 \pm 90$

Sphagnum peat just below Q-392, and immediately below the same recurrence surface. Comment: the age agrees closely with that for Q-392, and both are near the values for the retardation layer at Tregaron (Q-75, Q-390, this date list). Miss Turner has detailed pollen analyses (unpub.) at the site of sampling.

Q-434. Fenn's Moss, site B, upper

$1670 \pm 110$

Sphagnum peat immediately above the recurrence surface of this bog, site $B$.

Q-435. Fenn's Moss, site B, lower

$1842 \pm 110$

Sphagnum peat from just below Q-434, and immediately beneath the recurrence surface, site $B$.

\section{Q-383. Whixall Moss, Shropshire}

Pine wood $\left(52^{\circ} 55^{\prime} \mathrm{N}\right.$ Lat, $2^{\circ} 46^{\prime} \mathrm{W}$ Long $)$, from pine stump layer presumed to be that described by Hardy (1939), and from which a Middle Bronze Age palstave was reported to have come. It forms the third recurrence surface from the top. Coll. 1959 by H. Godwin. Comment: the radiocarbon date is too young for the Middle Bronze Age but might relate to the main recurrence surface at Tregaron and elsewhere; if so, Hardy's pollen zones might need reconsideration. Whixall and Fenn's Moss are continuous.

\section{Scaleby Moss series, Cumberland (continued)}

Sphagnum peat $\left(54^{\circ} 51^{\prime} \mathrm{N}\right.$ Lat, $2^{\circ} 52^{\prime} \mathrm{W}$ Long) at levels higher than those published in Cambridge 1 (Godwin and Willis, 1959). The depths correspond to those on the detailed pollen diagram B, given by Codwin, Walker, and Willis (1957). Coll. 1955 by D. Walker.

Q-168. Scaleby, 89 to $91 \mathrm{~cm}$

$5430 \pm 130$

Sphagnum peat at a level where the beginning of extensive aquatic pool peat formation above humified Sphagnum-Calluna-Eriophorum peat indicates the recurrence surface. The level is just below the pollen-zone boundary VII $a$ / VIIb (Godwin, Walker, and Willis, 1957).

Q-174. Scaleby, 48 to $50 \mathrm{~cm}$

$4440 \pm 130$

Sphagnum peat of very slight humification overlying more humified Sphagnum-Calluna peat at a recurrence surface. This level is in the lower part of pollen zone VIIb (Godwin, Walker, and Willis, 1957). 
Q-176. Scaleby, 16 to $18 \mathrm{~cm}$

$3895 \pm 130$

Very fresh Sphagnum peat forming a thin layer in somewhat less humified Sphagnum peat with some Calluna, indicating a weak recurrence surface.

\section{Comment on Recurrence Surfaces Series as a Whole}

The results grouped under this head can be supplemented by those from section A, especially the dates associated with the trackways of the Late Bronze Age, for these also occur at an horizon where sudden increase in wetness caused flooding of the bog surface. The horizon of the Neolithic trackways may have a similar significance but is less well defined.

The results as a whole seem to indicate the reality of climatically controlled recurrence surfaces rather widely represented, and some correspondence with the sequences suggested by Granlund and by Nilsson (see Godwin, 1956). It is apparent, however, that only very numerous and careful investigations can finally resolve the matter.

\section{Prehistoric Agriculture}

\section{Frogholt series, near Folkestone, Kent}

Organic mud and wood from various levels in fluviatile deposit, altitude $200 \mathrm{ft}$ 0.D., at Frogholt $\left(51^{\circ} 6^{\prime} \mathrm{N}\right.$ Lat, $1^{\circ} 6^{\prime} 13^{\prime \prime} \mathrm{E}$ Long), near Folkestone, Kent. Coll. 1958 by H. Godwin.

Q-348. Frogholt, 0 to $2 \mathrm{~cm}$

$2490 \pm 130$

Coarse detritus organic mud at surface of deposit, 0 to $2 \mathrm{~cm}$ depth. Pollen analyses prove widespread disforestation and extensive agriculture of surrounding Chalk Downs.

Q-349. Frogholt, 20 to $22 \mathrm{~cm}$

$2640 \pm 110$

Coarse detritus organic mud at 20 to $22 \mathrm{~cm}$ depth. Pollen analyses show considerable agriculture before the great expansion dated by Q-348.

Q-354. Frogholt, 90 to $100 \mathrm{~cm} \quad 2980 \pm 130$

Wood from basal part of same series as Q-348 and Q-349, at 90 to 100 $\mathrm{cm}$ depth. Pollen analyses show considerable agriculture. Cut wood, charcoal, and introduced stones show local prehistoric occupation of the valley site. Coll. 1958 by H. Godwin.

\section{Wingham series, Kent}

Organic mud from valley fen deposit $\left(51^{\circ} 15^{\prime} 50^{\prime \prime} \mathrm{N}\right.$ Lat, $0^{\circ} 13^{\prime} 23^{\prime \prime} \mathrm{E}$ Long), $230 \mathrm{~cm}$ deep, pollen-analyzed throughout, Wingham, Kent. Coll. 1955 by H. Godwin and R. G. West.

\section{Q-106. Wingham, 90 to $100 \mathrm{~cm}$}

Coarse detritus mud of reed swamp from valley fen deposit. RomanBritish occupation in upper layers and Neolithic on mineral surface below. Comment: cf. Q-110.

Q-110. Wingham, 175 to $185 \mathrm{~cm}$

$3105 \pm 110$

Fine detritus organic mud with fine sand from same site as Q-106. Comment: the two radiocarbon dates give a basis for the chronology of the whole 
deposit; extrapolation of this with pollen-analytic results suggests that from about 1600 в.c. to Roman time the Chalk here was open disforested country with arable land and pasture. Evidence of brackish water at the base of the deposit shows that the sea had reached its present height at or before 1600 B.c.

\section{Holme Fen series, Huntingdonshire}

Wood from various levels in raised bog $\left(52^{\circ} 28^{\prime} 56^{\prime \prime} \mathrm{N}\right.$ Lat, $0^{\circ} 13^{\prime} 23^{\prime \prime} \mathrm{W}$ Long), Holme Fen, Huntingdonshire, site 1. Coll. 1959 by H. Godwin and Vishnu-Mittre.

Q-403. Holme Fen, Site 1, $65 \mathrm{~cm}$

$3400 \pm 120$

Twigs of Calluna vulgaris coll. from the upper of two thin clay layers from the upper layers of the bog. These layers have been shown (VishnuMittre, unpub.) to represent the marginal extension of the Fen Clay of the East Anglian Fenland; they also represent the pollen-zone boundary of the later decline of Tilia relative to Ulmus and Quercus. Comment: cf. Q-404.

Q-404. Holme Fen, Site 1, $70 \mathrm{~cm}$

$3415 \pm 120$

Twigs of Calluna vulgaris and shoots of Eriophorum vaginatum picked out from the lower of the two clay layers, $5 \mathrm{~cm}$ below Q-403. Comment: the results for Q-403 and 404 agree closely and accord with the known stratification of Early Bronze Age artifacts into peat just above the Fen Clay elsewhere in the Fenland. Unpublished pollen analyses (Vishnu-Mittre) show a pronounced but temporary phase of agricultural activity at this level, and Middle Bronze Age artifacts have been found locally at a nearly identical pollen horizon (Godwin, 1942). The material of Q-403 and 404 was hand-picked to avoid the secondary root penetration that vitiated samples Q-276 and 277, not published because clearly erroneous.

Q-405. Holme Fen, Site 1, $135 \mathrm{~cm}$

$4190 \pm 130$

Betula wood grown in situ in fen wood peat just below base of ombrogenous Sphagnum peat. Very slight agricultural activity. Comment: the date accords satisfactorily with those for Q-404 and Q-406, between which it lies about midway in the section.

Q-406. Holme Fen, Site 1, $205 \mathrm{~cm}$

$4958 \pm 130$

Wood (? Alnus) grown in situ in Cladium fen. At important pollen-zone horizon of the earlier decline of Tilia relative to Ulmus and Quercus (Godwin and Gifford, 1938), also at level of the earliest sign of agricultural activity in this and neighboring pollen diagrams (Vishnu-Mittre, unpub.). Comment: date of 3000 B.c. suggests that the Tilia decline in this area may correspond with the conspicuous Ulmus decline in other regions. The date for initial forest clearance corresponds satisfactorily with other data for the introduction of the Neolithic cultures into Britain.

\section{E. Miscellaneous}

Q-68. Kate's Pad, Pilling, Lancashire

$2760 \pm 120$

Wood ( $53^{\circ} 54^{\prime}$ N Lat, $2^{\circ} 54^{\prime}$ W Long), from prehistoric track embedded in peat of a raised bog. The track consisted of longitudinally arranged split logs running approximately NE/SW. The track lies at the transition from wet 
fen peat to ombrogenous peat. Dr. Walker has an unpublished pollen diagram from the site. Coll. 1949 by D. Walker. Comment: date indicates construction in the Late Bronze Age as with the Somerset tracks (section A) and Q-77 (below).

Q-77. Brigg trackway, Lincolnshire

$2552 \pm 120$

Wood $\left(53^{\circ} 33^{\prime} \mathrm{N}\right.$ Lat, $0^{\circ} 30^{\prime} \mathrm{W}$ Long), from level of prehistoric wooden trackway which lies at a level where fen brushwood gives place to alluvial clay, and where a Late Bronze Age spearhead has been shown to have lain (Smith, 1959). Coll. 1933 by E. H. Rudkin; subm. by A. G. Smith. Comment: date agrees with the archaeologic and pollen-analytic evidence and gives a precise date for this marine transgression in the Humber-Ancholme valley.

\section{Q-303. Ehenside Tarn, Cumberland $\quad 4051 \pm 115$}

Wood $\left(54^{\circ} 27^{\prime} \mathrm{N}\right.$ Lat, $3^{\circ} 32^{\prime} \mathrm{W}$ Long), part of a stake driven through the occupation platform found in unpublished excavations by S. Piggott and D. Walker. Coll. 1957 by D. Walker. Comment: platform may represent the long-known Neolithic "A" culture at this site. Libby gave the date (C-462) of 4964 \pm 300 (Arnold and Libloy, 1951), but this applied to wood of very uncertain provenance (fide S. Piggott).

\section{Q-214. Ballyhalbert, Co. Down, N. Ireland $8120 \pm 135$}

Wood ( $54^{\circ} 30^{\prime} \mathrm{N}$ Lat, $5^{\circ} 29^{\prime} \mathrm{W}$ Long), from uppermost layers of the peat bed that underlies the $25 \mathrm{ft}$ raised beach. Bark of timber intact and only outer rings dated. Present altitude ca. $6 \mathrm{ft} 8 \mathrm{in}$. above sealevel, pollen zone VIc. Coll. 1957 by M. E. S. Morrison. Comment: date represents the resultant effect of the main eustatic rise of ocean level overtaking isostatic uplift at this place; it agrees with the pollen-analytic result from this and similar sites.

\section{Q-394. Llyn Teifi, Cardiganshire}

$5261 \pm 120$

Pine wood $\left(52^{\circ} 17^{\prime} \mathrm{N}\right.$ Lat, $3^{\circ} 47^{\prime} \mathrm{W}$ Long), from layer of pine stumps on mineral soil, and overlain by blanket bog: now exposed by the lake shore at $1328 \mathrm{ft}$ o.D. A similar basal wood layer occurs at other places round the lake; the surrounding hills are now bare of woodland. Coll. 1959 by H. Godwin and J. Turner.

\section{FRANCE}

Q-314. Mouligna, near Biarritz, SW France, $70 \mathrm{~cm} \quad 5010 \pm 130$

Wood $\left(43^{\circ} 25^{\prime} \mathrm{N}\right.$ Lat, $1^{\circ} 49^{\prime} \mathrm{W}$ Long), in a coastal exposure of a mud bed, at a level coresponding with the abundant prehistoric industry of "Asturian" type and less certainly with Neolithic pottery. At this level pollen analyses show a forest clearance phase (F. Oldfield, unpub.). Coll. 1957 by F. Oldfield.

SOUTH ITLANTIC

Q-417. Albatross Plain, Gough Island, 213 to $218 \mathrm{~cm} \quad 4720 \pm 130$

Sphagnum-Cyperaceae-Empetrum peat $\left(40^{\circ} 20^{\prime} \mathrm{S}\right.$ Lat, $10^{\circ} \mathrm{W}$ Long), at base of pollen-analysis series analyzed by U. Hafsten (unpub.). Immediately 
over bedrock. Coll. 1957 by N. M. Wace and M. Holdgate. Comment: this date in conjunction with the pollen analyses establishes a remarkably uniform vegetation for the past $4700 \mathrm{yr}$.

Q-418. Albatross Plain, Gough Island, 180 to $184 \mathrm{~cm} \quad 2345 \pm 120$

Peal $\left(40^{\circ} 20^{\prime} \mathrm{S} \mathrm{Lat}, 10^{\circ} \mathrm{W}\right.$ Long), enclosing a thin layer of volcanic ash, from same boring as Q-417. Coll. 1957 by N. M. Wace and M. Holdgate. Comment: this establishes a date for a volcanic eruption on the island (possibly the latest ): the $40 \mathrm{~cm}$ of peat between samples Q-4.17 and Q-4.18 would seem to represent as long a time period as the $180 \mathrm{~cm}$ formed after Q-4.17 was deposited.

\section{NUCLEAR WEAPON TESTING AND THE ATMIOSPHERIC \\ RADIOCARBON CONCENTRATION AT CAMBRIDGE, ENGLAND}

The presence of a very comprehensive seed collection at the National Institute of Agricultural Botany, Cambridge, afforded a unique opportunity to measure the rise of the atmospheric radiocarbon concentration during recent years. Oat samples from the harvests of each year from 1953 to 1959 were taken for assay, and the results shown are measured with respect to their percentage variation from the 1953 value. Oats have a very short growing season, and photosynthesize principally at the time of the year when Münnich and Vogel (cee Godwin, 1959) have demonstrated that the seasonal radiocarbon variation has reached its maximum. The crops were grown in and around Cambridge, and thus the measurements from year to year are directly comparable.

Q-436. Grains of oats grown in Cambridge in 1953.
Q-437.
$Q-4.38$.


in the main from the previous season's cereal and root crops. Medical evidence suggests that carbon in the hair is derived entirely from the current carbohydrate intake.

\section{CHECK SAMPLE}

\section{Q-462. Interlaboratory check}

Oxalic acid, National Bureau of Standards, Washington. Activity as percentage above Cambridge 1850 oak wood standard.

\section{SEQUOIA RING-DATING EXPERIMENT}

The joint experiment undertaken by Cambridge, Heidelberg, and Copenhagen to assay at 50 -yr intervals the atmospheric radiocarbon concentration of the last 1300 years is reported separately in this issue of the RADIOCARBON SuPPlEMENT, p. 1-4.

\section{REFERENCES}

Arnold, J. R., and Libby, W. F., 1961, Radiocarbon dates: Science, v. 113, p. 111-120.

Clapham, A.' R., and Godwin, H., 1948, Studies of the Post-glacial history of British vegetation. VIII. Swamping surfaces in peats of the Somerset Levels: IX. Prehistoric trackways in the Somerset Levels: Royal Soc. [London] Philos. Trans., ser. B, v. 233, p. $233-273$.

Godwin, H., 1942, A Middle Bronze Age palstave from buried forest at Woodwalton Fen, Hunts.: New Phytologist, v. 4l, p. 166-170. Hunts.: New, The relationship of bog stratigraphy to climatic change and archaeology: Proc. Prehist. Soc., v. 12, p. 1-11. $384 \mathrm{p}$ 1956, The history of the British flora: Cambridge, Cambridge University Press,

1959, Carbon-dating conference at Groningen: Nature, v. 184, p. 1365-1366.

in press, Prehistoric wooden trackways of the Somerset Levels: their construction, age, and relation to climatic change. Proc. Prehist. Soc.

Godwin, H., and Gifford, M. H., 1938, Studies of the Post-glacial history of British vegetation. I. Origin and stratigraphy of Fenland deposits near Woodwalton, Hunts.: Royal Soc. [London] Philos. Trans., ser. B, v. 229, p. 323-363.

Godwin, H., and Mitchell, G. F., 1938, Stratigraphy and development of two raised bogs near Tregaron, Cardiganshire: New Phytologist, v. 37, p. 425-454.

Godwin, H., Walker, D., and Willis, E. H., 1957, Radiocarbon dating and post-glacial vegetational history: Scaleby Moss: Royal Soc. [London] Proc., ser. B, v. 147, p. $352-366$.

Godwin, H., and Willis, E. H., 1959, Cambridge University natural radiocarbon measurements. I: Am. Jour. Sci. Radioc. Supp., v. 1, p. 63-75.

1959, Radiocarbon dating of prehistoric wooden trackways: Nature, v. 184, p. $490-491$

Hardy E M. 1939. Studies of the Post-glacial history of British vegetation. V. The Shropshire and Flint Maclor mosses: New Phytologist, v. 38, p. 364-396.

Smith, A. G., 1959, Post-glacial deposits in South Yorkshire and north Lincolnshire: New Phytologist, v. 57 , p. $19-49$

Willis, E. H., 1960, The atmospheric radiocarbon activity in 1959: Nature, v. 185, p. 552

Willis, E. H., Tauber, H., and Münnich, K. O., 1960, The variations in atmospheric radiocarbon activity over the past 1300 years: Am. Jour. ScI. Ravioc. Supp., v. 2, p. 1-4. 